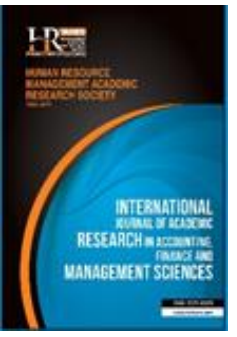

International Journal of Academic Research in Accounting, Finance and Management Sciences

Vol. 9, No. 3, July 2019, pp. 38-48

E-ISSN: 2225-8329, P-ISSN: 2308-0337

(c) 2019 HRMARS

www.hrmars.com

To cite this article: Nasiri, A., Noori, A., Salleh, M.C.M. (2019). Acceptance and Practices of Cash WAQF among University's Students, International Journal of Academic Research in Accounting, Finance and Management Sciences 9 (3): 38-48

\title{
Acceptance and Practices of Cash WAQF among University's Students
}

\section{Abdulrahim Nasiri ${ }^{1}$, Abdullah Noori ${ }^{2}$, Marhanum Che Mohd Salleh ${ }^{3}$}

${ }^{1}$ Postgraduate students Kulliyah of Economics and Management Sciences (IIUM), Emails: Abdullahnoori12@gmail.com,Abdulrahim.nasiri93@gmail.com

${ }^{2}$ Department of Finance Kulliyah of Economics and Management Sciences (IIUM)

\begin{abstract}
Innovation in Waqf (Islamic endowment) in the modern century has made movable asset like cash Waqf practices possible. This research further examines the awareness, acceptance, and practices of cash Waqf among university students. Other objective is to evaluate their perception towards the management of cash Waqf in Malaysia. To achieve the objectives, primary data were collected through survey among 160 International Islamic University Malaysia (IIUM) students. Based on few statistical analyses, results revealed that even though IIUM students have moderate level of awareness towards cash Waqf, they were basically have high level of acceptance and practices towards the implementation of cash Waqf in the country. Hence, cash Waqf practices should be continued and innovate for future benefits to the society.

Key words Cash Waqf, Acceptance, Malaysia, University's Students, Regression Analysis

Received: 20 Aug $2019 \quad$ C The Authors 2019

Revised: $\quad 30$ Aug 2019 Published by Human Resource Management Academic Research Society (www.hrmars.com)

Accepted: $\quad 04$ Sep 2019 This article is published under the Creative Commons Attribution (CC BY 4.0) license. Anyone may Published Online: 14 Sep 2019 reproduce, distribute, translate and create derivative works of this article (for both commercial and non-commercial purposes), subject to full attribution to the original publication and authors. The full terms of this license may be seen at: http://creativecommons.org/licences/by/4.0/legalcode
\end{abstract}

\section{Introduction}

Recently, Waqf activity has gained its popularity not only in Malaysia but also in other countries. According to Dzuljastri (2015), Malaysia has pioneered in the establishment of countless funds that are aimed towards the development of the Ummah (nation). In Malaysia, Waqf land and building is a common practice of Waqf, but cash Waqf is still considered as a new form of Waqf. Malaysia has practiced a decentralization of Waqf management where control over waqf assets is placed under state religious council. Cash Waqf is being practiced in several states in Malaysia which are Selangor, Kedah, Perak, Pulau Pinang, and Johor even though the practice is still at infancy level. The Waqf centers and religious state department in Malaysia are also active in building more contemporary Waqf instruments which are useful for the society (Farha et al., 2014). Most of Malaysians believe that Waqf is only obligated for Muslims society, while non-Muslims also can contribute to the Waqf endowment. The information is not spread among the public and hence the low level of awareness on Waqf among the public. Besides that, the significant contribution of Waqf towards Islamic economics is not realized by most of the Muslim community. Public perceived zakat as the best tool to reduce poverty and help the needy, this is supported by a survey conducted in 2008 by MAIS which reveals that approximately 70 percent of Malaysian Muslims do not know about the Waqf practice done by the institution (Puad et al., 2014).

Accordingly, compare to other form of waqf, cash Waqf has a bigger potential of income generation due to its liquidity that can be utilize for many activities. In addition, cash Waqf can solve the problem of 
unproductive Waqf properties involving tangible assets due to its illiquid in nature and have limitation of utilisation. Mochammad and Dimas (2011) believe that the principle and spirit of Waqf are a fundamental to build a strong society which in the aspect of education, health welfare, and social security (Syadiyah et al., 2017). It also benefits the investors, financial institutions, and societies (Amirul et al., 2012).

Cash Waqf can enhance Muslim welfare particularly poor and needy segments and as part of poverty alleviation and redistribution of wealth in reducing the gap between the poor and rich. If Waqf is being practiced at the macroeconomic level, it is believed that Waqf system would contribute to the reduction of government expenditure which leads to smaller budget deficit and leads to lower borrowing rate. Hence, it may lower down the rate of interest, consequently reining in a basic impediment to growth and private investment (Cizacka, 2000).

One of the factors that contributed to the success of cash Waqf is the efficient management of cash Waqf. A transparent and professional cash Waqf management is very important to determine the success of cash Waqf. Yet, because of poor management and administration of Waqf properties, the credibility of Waqf institutions is being debated by many parties (Ihsan, 2011). In Jakarta and West Java, a study by Masyita (2005) has found that most of the people have low level of trust on public Waqf institutions in Indonesia. This is because many Waqf management committees are involved with endowments of a substantial number of properties (Masyita, 2005). This is supported by Khamis and Mohd Salleh (2018) who agrees that due to several internal management issues the cash Waqf management efficiency is still questionable.

Moreover, the issue of Waqf management arises because of technical expertise and lack professional in managing the Waqf asset which remains as a challenge faced by MAIS. Unidentified replacement for secondment cases within the MAIS organization itself is another issue which significantly impacts the terms of Waqf timeliness process, particularly when the important decisions are made by the secondment.

Despite its potential, understanding and awareness level of public is still low on cash Waqf. The amount of cash Waqf collected still at infancy level and do not generate sufficient funds of scale to carry out the program with impact as compared with Singapore that has shown a significant amount of collection though ruled by a secular government (Amirul et al., 2012). Thus, this research examines the awareness, acceptance, and practices of cash Waqf among university students in Malaysia. Other objective is to evaluate their perception towards the management of cash Waqf.

\section{Literature review}

\subsection{History of cash Waqf}

Waqf is an Arabic word that comes from the root word of Waqafa which means to hold or detain. Technically, Waqf is transferring the ownership of a property to the ownership of Allah. Lahsasna (2010) argued cash Waqf is mobilization funds from donors based on perpetuity and investing them in productive assets that provide either usufruct or revenues. This profit should be used for the future consumption whether by group or individual by considering the guideline and policy provided by the donors and receivers. From the economic perspective, it can be explained that, transferring funds from consumption to investment assets which generate either revenues or usufruct for the groups of individuals or individual for the future consumption (Mohammad and Dimas, 2011). It is an act to forgone current consumption for productive benevolent purposes.

Waqf is an act of volunteer charity for the sake of Allah and not considered as part of a compulsory act. Waqf is an act of charity and considered variously in Islam as a purification of the soul, a spiritual discipline, and assistance to fellow human beings (Amirul et al., 2012). Thus, it is highly encouraged in Islam as it can directly contribute to economic development and Muslim's social wellbeing. In a hadith narrated by Abu Huraira (May Allah be pleased with him) he reported Prophet Muhammad (PBUH) as saying: "When a man dies, all his acts come to an end, except these three; recurring charity (sadaqa jariya), knowledge (by which people benefited), and a pious offspring, who prays for him". It is relatable that cash Waqf is a recurring charity where the donor will receive a continuous reward from Allah S.W.T.

The practice of cash Waqf is not new. The history of cash Waqf can be traced since the Prophet Muhammad era which has proven its success in implementation. According to Sanusi and Shafiai (2015), Waqf was introduced during Prophet Muhammad's (PBUH) era with the built of Quba' Mosque on the first 
Waqf land in Medina which was built upon the arrival of Prophet Muhammad S.A.W. on his migration to Medina.

Cizkca (2010) argued that the concept of cash Waqf has begun since Tabi'in century narrated by Imam Muhammad bin Ismail Al-Bukhari. According to the narration, Imam Al-Zuhri was asked about a man endowed 1000 dinar to a businessman as a cash capital and the profit will be distributed to the poor. According to Kuran (2009), the concept of Waqf was elucidated after a century from the beginning of Islam, while started practically in the second and third century of Islam. In addition, this concept was supported by clear evidence from the companion of the Prophet (PBUH) such as Roma was endowed by Ottoman (RA) and Khaiber land by Umar (RA). After Imam Malik and Zufar time, the practice of cash Waqf was practiced in Fes in Morocco and by the Ottoman Empire. The Ottoman Empire successfully practiced cash Waqf for a very long time and gave positive impacts in the reduction of poverty. The city of Fes in Morocco practiced cash Waqf for lending and borrowing without additional payment to the principal during repayment (Amir, 2013).

\subsection{Awareness and Acceptance of cash Waqf}

Amirul et al. (2012) studied the determinants of cash Waqf giving in Malaysia by studying few determinants such as religious satisfaction, literacy of Waqf, trustworthiness, demographic factor, efficient management, and tax incentive. The study is to develop a clear understanding with regard to the further development of cash Waqf in Malaysia through exploratory studies. The study reveals that religious satisfaction affects cash Waqf giving as a form of intrinsic motivation besides trust towards Waqf administration and management. The authors highlighted that literacy on Waqf is very important as lacks of literacy among people leads to ineffective cash Waqf raising besides narrow understanding on Waqf diversity. The authors added that demographic factors, efficient management, and tax incentives also play a positive role in determining cash Waqf giving in Malaysia.

Adeyemi et al. (2016) attempted to study the determinants of cash Waqf awareness in Malaysia. The main objective of this study, therefore, is to empirically evaluate the awareness level about cash Waqf among Malaysian Muslims. The empirical evidence suggested that the awareness level of cash Waqf is still low among Malaysian Muslims. The results also supported that low awareness is due to factors such as lack of understanding, lack of promotion and the influence of social culture.

Mardziyah (2014) studied the factors influencing the acceptance of online Waqf in Islamic banking institutions. A statistical method such as Independent Samples T-Test, Analysis of Variance (ANOVA), Pearson Correlation and Multiple Linear Regression analysis were employed to archive the objectives of this research. The results suggested that four variables are positively correlated at $95 \%$ and $99 \%$ of confidence level with the acceptance of online Waqf. From the research, it is known that there are three factors significantly influencing the acceptance of online Waqf which is perceived usefulness, perceived ease of use and amount of information found in. However, there other two factors which are perceived religiosity and perceived self-efficacy are found to be an insignificant factor influencing the acceptance of online Waqf in the Islamic banking institution.

\subsection{Permissibility of cash Waqf}

According to the majority of Muslim scholars, the most applicable condition for the Waqf is that the Waqf asset should be perpetual and should not be diminished by using or utilizing. However, Malikies do not impose that condition and allowed assets like food to give in Waqf. According to Imam Muhammad all durable assets are allowed to be endowed which are recognized by the local custom. Based on Shafi' is and Hanbalis opinion, the permissibility of Waqf is not limited only to property and even the movable assets can be endowed.

Syadiyah et al. (2017) studied Muslim attitude towards participation in cash Waqf in Malaysia and found that individual religiosity, trust in Awqaf institutions and convenience to endow are determinants of Muslim attitude towards participation in cash Waqf, which consequently leads to individual intention to participate in the practice. This study expands the literature and very relevant to the Waqf institution and Islamic regulatory body in executing an effective strategy to promote cash Waqf as well as reinforcement of systematic collection procedures that can benefit the community. 
Mochammad and Dimas (2011) studied the significance of cash Waqf from a macroeconomics perspective. The authors believe that cash Waqf is very significant and important in reducing government expenditure and participation in the economy, preventing deficit financing and decreasing rate of interest, eradicating poverty as a micro-financing tool and enhancing economic progress since the early Muslim civilization. Furthermore, it can provide entrepreneurial opportunity and reducing the unemployment rate among Muslims. Due to the high potential of Waqf, the authors emphasized the importance of revitalization of cash Waqf in Malaysia.

\subsection{Perceptions towards the management of cash waqf}

Few studies have been done on the management and administration of Waqf in Malaysia. Among other is research by Puad et al. (2014) who studied the issues and challenges of Waqf management is Selangor state which is managed by Majlis Agama Islam Selangor (MAIS). The authors highlighted several issues related to the Waqf such as lack of awareness and not getting enough funds. The authors believed there several significant impacts of Waqf to the economic development of Selangor state and poverty eradicating. However, according to them, there is a legal constraint Waqf land administration system in Malaysia that might distort the potential of Waqf in Malaysia.

Mohamed Isa et al. (2011) agreed that efficient and systematic Waqf land management is very important to benefit the Muslims. The authors have conducted a research on the state Waqf management institution in Malaysia namely Majlis Agama Islam Selangor (MAIS), Majlis Agama Islam Kedah (MAIK), Majlis Agama Islam Negeri Pulau Pinang (MAINPP), Majlis Agama Islam Wilayah Persekutuan Kuala Lumpur (MAIWP) and Jabatan Agama Islam Melaka (JAIM). MAIS has introduced Selangor Share Scheme and the collection of the Waqf is put into a Cash Waqf Group Fund to be managed. MAIK has introduced "Waqf Jemba" that involves property or land Waqf while MAINPP focused on commercial land building Waqf and MAIWP focuses on general Waqf. In order to ensure smooth running and efficient Waqf management, JAIM has developed a very systematic database, Peringgit to identify cemetery's data in An-Nur Mosque. The authors have also studied Waqf Management by Singapore managed by Majlis Ugama Islam Singapore (MUIS) which have issued $\mathbf{S} 25$ million Musharakah bond for the purchase of a building.

Khamis and Salleh (2018) studied the current management issues of cash Waqf in Malaysia. Through the exploratory studies conducted, the authors found that only three Waqf institutions in Malaysia have specific Waqf enactment. The authors emphasized the importance of trained staff, proper documentation and reporting are very important in managing cash Waqf in Malaysia.

Saad et al. (2013) emphasized that effective management of Waqf institution is very important as it interacts directly with the society directly similar to Corporate Social Responsibility (CSR). The authors investigated the effectiveness of two private Waqf institutions in Malaysia and Singapore. The authors concluded that the three Waqf institutions has adopted a more structured approach in financing the development of their Waqf properties and experimenting new ways of managing and investing the Waqf asset.

Rusydiana and Devi (2018) studied the development of cash Waqf in Indonesia and the barriers towards the development. The authors discovered that there are several issues related to the cash Waqf management in Indonesia which are lack of trust among donator, Shariah problem, misappropriation of Waqf fund and weak management system.

Ismail et al. (2015) highlighted several prominent issues pertaining to Waqf practice which includes ownership and registration of Waqf land, financial problems, shortage of competent Waqf managers and illegal occupation and intrusion of Waqf land. According to them, Waqf institutions in Malaysia seem to fail to play a dynamic role in uplifting the development and economy of the Muslims. The authors agreed that the absence of legal provisions for the administration of Waqf in the past had resulted in inefficient and unsystematic administration of Waqf land or properties. It was also highlighted that improper and unsystematic record of Waqf asset results in manipulation of Waqf properties.

In their research on Waqf management, Chowdhury et al. (2012) highlighted some problems related to Waqf management. They argued that Waqf should be managed by qualified, knowledgeable and professional managers and it is found that some Waqf managers are not qualified and not competent. They 
also claimed there some issues where Waqf asset are managed by non-Muslim and there are some Waqf properties left idle due to procrastination in the management process.

\section{Methodology of research}

This study adopts quantitative method to achieve all research objectives stated earlier. A structured questionnaire is prepared and distributed to 160 IIUM students around the campus. Likert scale is utilized to ease the respondents to pick up their desired options.

Statistical Package for the Social Science (SPSS) software and AMOS is used to run the data with various types of analyses which including correlation, regression analysis, and ANOVA.

Overall, there is one dependent variable which is level of acceptance of cash Waqf and three independent variables which are awareness, management of cash Waqf, and practice of cash Waqf. Following sections discuss results of this research.

\section{Research Findings}

Demographic analysis of the respondents.

Table 1. Demographic information of respondents

\begin{tabular}{|c|c|c|}
\hline \multicolumn{3}{|c|}{ Profile of the Respondents } \\
\hline & FREQUENCY & PERCENTAGE $\%$ \\
\hline \multicolumn{3}{|l|}{ Gender } \\
\hline Male & 118 & 73.8 \\
\hline Female & 42 & 26.3 \\
\hline \multicolumn{3}{|l|}{ Age } \\
\hline 20 or less & 3 & 1.9 \\
\hline $21-30$ & 106 & 66.3 \\
\hline $31-40$ & 35 & 21.9 \\
\hline $41-50$ & 11 & 6.9 \\
\hline $51-60$ & 4 & 2.5 \\
\hline 61 and above & 1 & 0.6 \\
\hline \multicolumn{3}{|l|}{ Marital Status } \\
\hline Single & 98 & 61.3 \\
\hline Married & 53 & 33.1 \\
\hline Divorced & 9 & 5.6 \\
\hline \multicolumn{3}{|l|}{ Education level } \\
\hline High school & 11 & 6.9 \\
\hline Diploma & 11 & 6.9 \\
\hline Bachelor Degree & 51 & 31.9 \\
\hline Master Degree & 73 & 45.6 \\
\hline PHD & 14 & 8.8 \\
\hline \multicolumn{3}{|c|}{ Formal Islamic education } \\
\hline Islamic school & 77 & 48.1 \\
\hline Islamic high school & 27 & 16.9 \\
\hline Personal effort & 48 & 30 \\
\hline University & 7 & 4.4 \\
\hline None & 1 & 0.6 \\
\hline Total & 160 & 100 \\
\hline
\end{tabular}

This survey was distributed among students by using link on social media. The majority of the respondents are male with $73.8 \%$, while only 42 females participated in the survey. Based Table 1 above, the highest number of respondents belongs to the age group of 21-30 years old with 106 responses. The second largest survey participants are from the age category of 31-40 with 21.9 percent. However, only one respondent belongs to the age group of 61 and more. Most of the respondents were single with 61.3 
percent of total respondents, whereas only 53 numbers of respondents were married. Interestingly, 9 of the participants were divorced.

Master degree forms the majority of our respondents with 73 responses followed by bachelor degree with 51 of the total respondents. A total of $14 \mathrm{PhD}$ students participated in the questionnaire, while high school and diploma students had the least number of respondents with 11 responses only. Most of our respondents had a background in Islamic education. The highest number of respondents had a formal Islamic education from Islamic school with 48.1 percent, whereas the 30 percent of the respondents got their Islamic education by personal effort. However, only 1 respondent had no Islamic education.

The above table shows the range, mean, Std deviation, the variance of the total respondents for this research paper. The mean for gender is 1.26 and the standard deviation is 0.441 . The mean for age group, marital status, education, and formal Islamic education is $2.44,1.44,3.43$, and 1.93 respectively. The standard deviation for age is 0.806 and 0.601 standard deviation for marital status.

Level of Awareness

Table 2. Awareness towards Cash Waqf

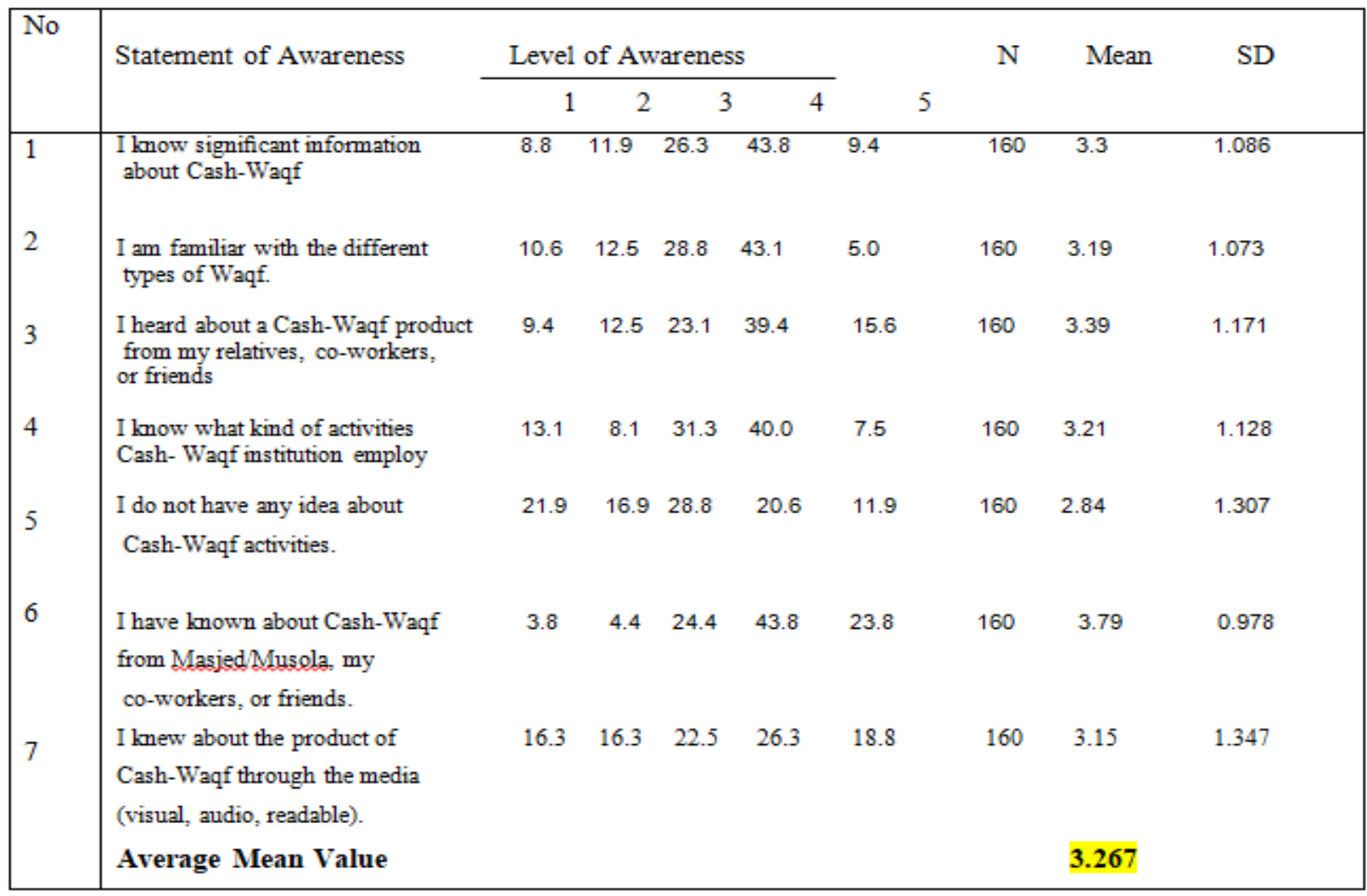

(1: Highly unaware), (2: Unaware), (3: Moderately aware), (4: aware), (5: Highly Aware)

To observe the level of awareness on cash Waqf among IIUM students, seven questions were asked to them. According to Table 2 above, mean value which is range from 2.84 to 3.79 indicate that the lowest mean was recorded for the statement, 'I have no idea about the activities of cash Waqf' which is 2.84 . However, the highest mean was recorded for the statement 'I know cash Waqf through my friends, coworkers, or Masjid' which was 3.79. Generally, IIUM students are moderately aware of cash Waqf based on an average mean value which is 3.267 .

Accordingly, for the first statement around $43.8 \%$ of respondents have significant information about the cash Waqf while $8.8 \%$ participants are highly unaware of the cash Waqf. Moreover, $43.1 \%$ of respondents are aware of the different types of cash Waqf, whereas only $12.5 \%$ of students are unaware of the different types of cash Waqf. In addition, the highest percentage of participants got information about cash Waqf from their friends, co-worker, relatives, and media. Lastly, the response of participants about 
the activities of cash Waqf was $28.8 \%, 21.9 \%$, and $20.6 \%$ moderately aware, highly unaware, and aware respectively.

Perception toward Management of cash Waqf

Table 3. Perception towards the Management of Cash Waqf

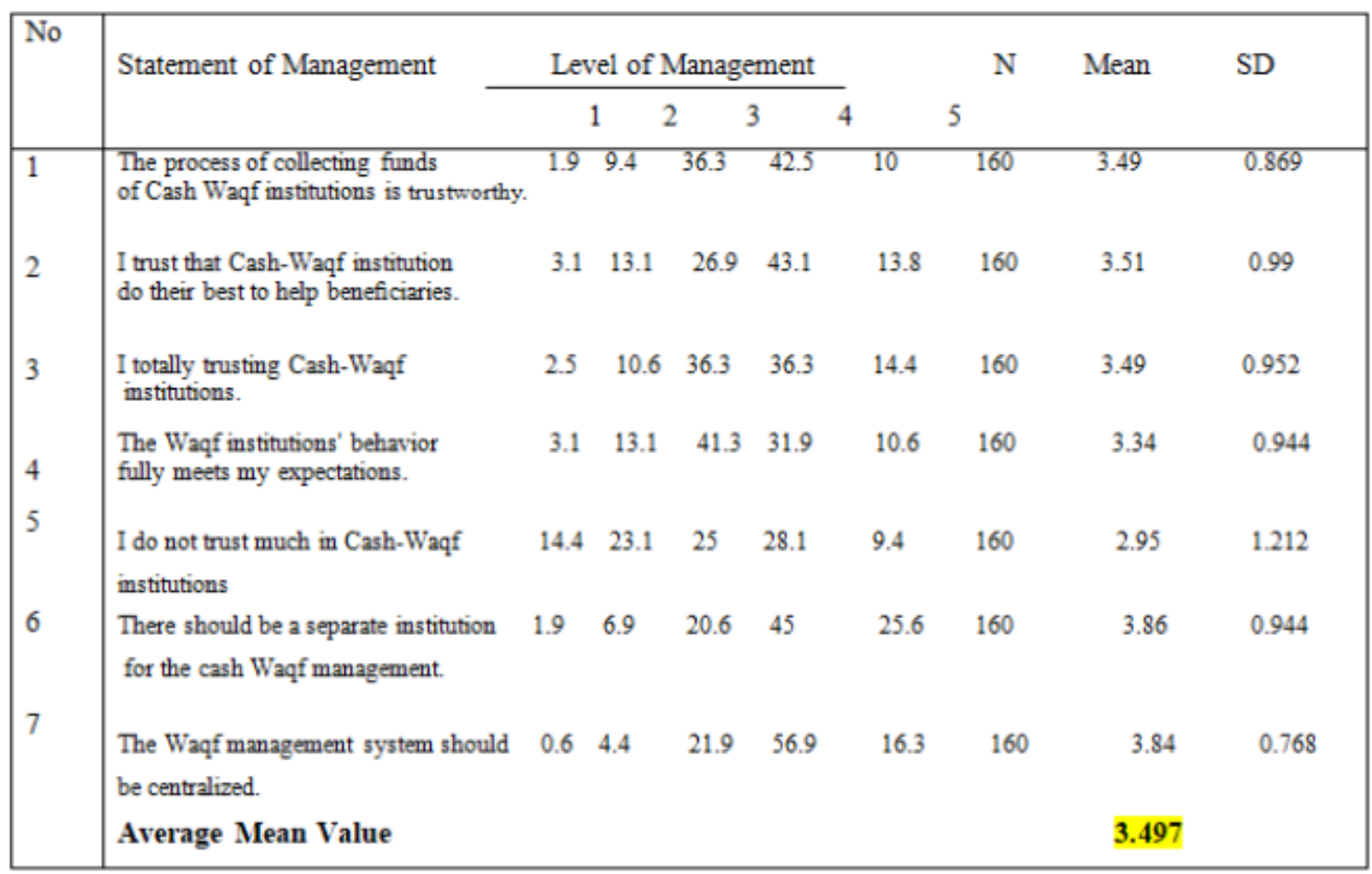

[1: Strongly disagree], [2: Disagree], [3: Neutral], [4: Agree], [5: Strongly Agree]

The second independent variable is the perception of IIUM students towards the management of cash Waqf which contains 7 questions. As mentioned in the above table, the mean value about the perception of cash Waqf management was ranked from 3.86 to 2.95. Additionally, the highest mean value was ranked for the statements of the cash Waqf should have a separate institution. However, the statement of I don't trust the cash Waqf institution has the lowest mean value. The overall mean value of respondents towards the management was 3.497 which mean their perception is good about the management of cash Waqf.

According to the above table, $42.5 \%$ respondents have trust on the cash Waqf institutions, while only $1.9 \%$ participants strongly disagree to have trust in the cash Waqf institutions. Likewise, 43.1 percent of participants agree that the cash Waqf institution helps the beneficiaries, whereas 3.1 percent of respondents highly disagree with that statement. Moreover, 41.3 percent of respondents show that they are neutral about the institution behavior and their expectations from the institutions. Generally, most of the respondents have a positive perception towards the cash Waqf management.

\section{Practices of Cash Waqf}

In this part, the respondents were asked their perception towards the permissibility of cash-Waqf. For the first statement, most of the respondents said that they have religious or moral obligation to contribute cash Waqf with $45.6 \%$ agree and $24.4 \%$ strongly agree. 80 percent of the participants agreed that donating to Waqf institution is a noble act. In addition, almost 73 percent of the respondents said that a cash Waqf is a permissible act in Islam. However, the statement of I will never endow cash Waqf, 50 
percent of the students strongly disagreed with the statement. The highest mean belongs to the second statement with 4.06, while statement 7 has the lowest mean with 2.64 only.

Table 4. Cash Waqf Practices

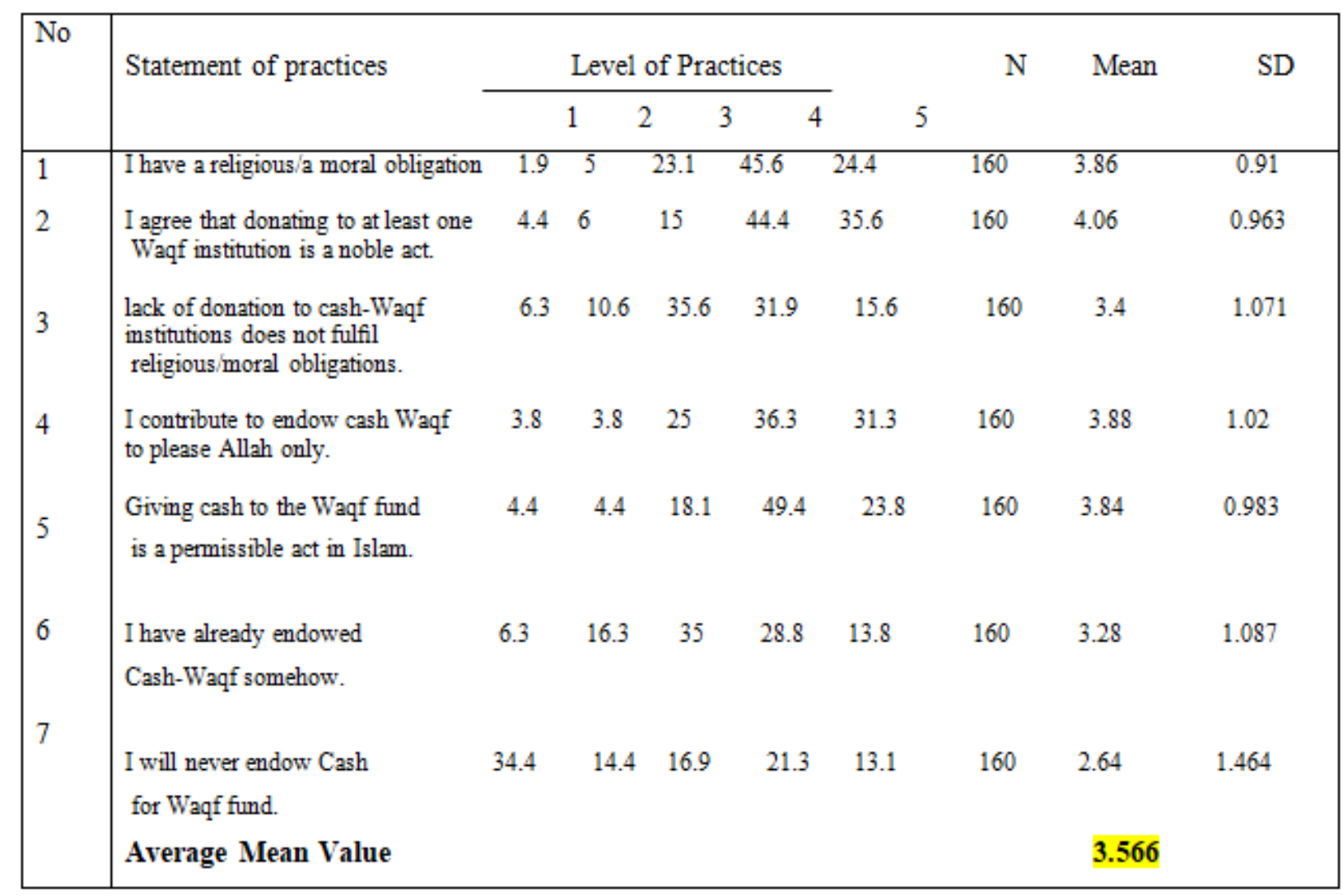

Acceptance of Cash Waqf

Table 5. Acceptance towards Cash Waqf 


\begin{tabular}{|c|c|c|c|c|c|c|c|c|c|}
\hline \multirow[t]{2}{*}{ No } & \multirow[t]{2}{*}{ Statement of Acceptance } & \multicolumn{4}{|c|}{ Level of Acceptance } & \multirow[b]{2}{*}{5} & \multirow[t]{2}{*}{$\mathrm{N}$} & \multirow[t]{2}{*}{ Mean } & \multirow[t]{2}{*}{$\mathrm{SD}$} \\
\hline & & & 1 & 2 & 3 & & & & \\
\hline 1 & $\begin{array}{l}\text { I have received enough information } \\
\text { about the benefits of using cash Waqf }\end{array}$ & 5.6 & 15 & 31.3 & 33.8 & 14.4 & 160 & 3.36 & 1.079 \\
\hline 2 & I intend to use cash Waqf in the future & 3.8 & 3.1 & 30.6 & 37.5 & 25 & 160 & 3.77 & 0.986 \\
\hline 3 & $\begin{array}{l}\text { I have positive perception about } \\
\text { the acceptance of cash Waqf }\end{array}$ & 1.9 & 6.3 & 20 & 45.6 & 26.3 & 160 & 3.88 & 0.934 \\
\hline 4 & $\begin{array}{l}\text { I believe it is highly rewarded } \\
\text { to participate in the cash Waqf. }\end{array}$ & 1.3 & 5 & 20.6 & 49.4 & 23.8 & 160 & 3.89 & 0.866 \\
\hline 5 & $\begin{array}{l}\text { Overall I believe cash Waqf is } \\
\text { a permissible form of Waqf } \\
\text { endowment. }\end{array}$ & 2.5 & 1.3 & 16.9 & 60.6 & 18.8 & 160 & 3.92 & 0.793 \\
\hline & Average Mean Value & & & & & & & 3.764 & \\
\hline
\end{tabular}

\section{Factors Determines Acceptance of Cash Waqf Practices}

There are five factors examined in this research that might influence the level of acceptance (Y1) among IIUM students towards cash waqf practices in the country. They are awareness $(x 1)$, perception on waf management $(x 2)$, and practice of Cash Waqf $(x 3)$. Linear equation was formed between three independent variables which simply accommodate the input value and one dependent variable which is relevant to the output. The basic model structure of the sample design of the research is:

$$
y=a+b_{1} x_{1}+b_{2} x_{3}+b_{3} x_{3}
$$

Table 6. Results of Regression Analysis

\begin{tabular}{|c|c|c|c|c|c|c|}
\hline \multicolumn{7}{|c|}{ Coefficients } \\
\hline \multirow{2}{*}{\multicolumn{2}{|c|}{ Model }} & \multicolumn{2}{|c|}{ Unstandardized Coefficients } & \multirow{3}{*}{$\begin{array}{c}\text { Standardized Coefficients } \\
\text { Beta }\end{array}$} & \multirow[t]{2}{*}{$\mathrm{t}$} & \multirow[t]{2}{*}{ Sig. } \\
\hline & & B & Std. Error & & & \\
\hline \multirow[t]{4}{*}{1} & (Constant) & 1.377 & .252 & & 5.460 & .000 \\
\hline & $\begin{array}{l}\text { Perception on Waqf } \\
\text { Management }\end{array}$ & .230 & .084 & .221 & 2.729 & .007 \\
\hline & Cash Waqf Practices & .282 & .073 & .305 & 3.832 & .000 \\
\hline & Awareness & .177 & .068 & .215 & 2.607 & .010 \\
\hline
\end{tabular}

$$
\begin{aligned}
& \boldsymbol{y}=\boldsymbol{a}+\boldsymbol{b}_{1} \boldsymbol{x}_{1}+\boldsymbol{b}_{2} \boldsymbol{x}_{3}+\boldsymbol{b}_{3} \boldsymbol{x}_{3} \\
& \mathrm{Y}=\mathrm{A}+\mathrm{B}_{1} \text { Perception on Management }+\mathrm{B}_{2} \text { Permissibility }+\mathrm{B}_{3} \text { Awareness } \\
& \mathrm{Y}=1.377+0.23 \text { (Perception on Management) }+0.282 \text { (Permissibility) }+0.177 \text { (Awareness) }
\end{aligned}
$$

Table 6 above shows the influence of three independent variables (awareness, waqf management perception, and cash waqf practices towards dependent variable (cash waqf acceptance). Based on regression results, level of significant show that there all the independent variables have positive influence towards the dependent variable at 0.05 significant level. In addition, results of standardized beta indicate that cash Waqf practices has the highest influence towards that acceptance of cash Waqf among the university student. With one unit change in Cash Waqf practices, the acceptance will increase by 31 
percent. On the other hand, awareness level has the lowest effect towards acceptance of cash Waqf, where its coefficient is 0.215 .

\section{Conclusions}

Waqf practices play a significant role in the Islamic economic system. To cater for modern needs, the contribution of cash Waqf is very vital in both micro and macro levels to enhance the welfare of Muslim society, and contribute to the eradication of poverty, treat the deficit, minimize government expenses, and reduce the gap between rich and poor people. Cash Waqf is a liquid form of Waqf asset which can fulfil the needs and demand of technological era for social services. However, there are some issues related to cash Waqf such as lack of awareness of the Muslims, misperception toward management and institution of cash Waqf, and misunderstanding about the permissibility of cash Waqf.

Therefore, in this paper we studied the perception of university students towards the cash Waqf as well as their level of acceptance. Generally, our findings show that most of the IIUM student was accepted the using of cash for Waqf purposes and they were willing to contribute their money for Waqf. Besides that, the perception of respondents was positive toward the management of cash waqf. It means that, they believe that cash Waqf institutions have fulfilled their responsibility as Waqf trustee and managed the Waqf assets well. In addition, they were in opinion that management of Waqf assets should be done by central body. Overall, it is found that all the independent variables (awareness, practices, and perception) have positive influence towards the acceptance level of cash Waqf among IIUM students.

\section{Acknowledgement}

The authors would like to thank the Malaysian Ministry of Higher Education for financial support under Fundamental Research Grant Scheme (FRGS19-016-0624).

\section{References}

1. Azniza, H. A. A. A., Mohamed, A. G. H. \& Hanira, H. (2018). "A Proposed Model for Waqf Fi Nancing Public Goods and Mixed Public Goods in Malaysia."

2. Adeyemi, A., Ismail, N., \& Hassan, S. S. (2016). An Empirical Investigation of the Determinants of Cash Waqf Awareness in Malaysia. Intellectual Discourse, 24. Retrieved from http://journals.iium.edu.my/ intdiscourse/index.php/islam/article/view/931

3. Amirul Faiz Osman, Sheila Nu Nu Htay And Muhammad, Mustafa Omar. 2012. "Determinants Of Cash Waqf Giving In Malaysia: Survey Of Selected Works." Animal Genetics 39(5): 561-63.

4. Budiman, M. A., \& Kusuma, D. B. W. (2011). The Economic Significance Of Waqf: A Macro Perspective. Faculty of Economic And Management Sciences, Students.

5. Devi, A. S.R. and Abrista. (2018). "Elaborating Cash Waqf Development In Indonesia Using Analytic Network Process." 3(8).

6. Farhah, B. S., Saim, K. \& Refik, P. (2014). "The Role of Cash Waqf In Poverty Alleviation: Case Of Malaysia." Notes And Queries S3-Viii(188): 119.

7. Ismail, C. Z., Nor, J. S., and Nor Jawanees, A. H. (2015). "Administration and Management Of Waqf Land In Malaysia: Issues And Solutions." Mediterranean Journal Of Social Sciences 6(4): 613-20. Http://Www.Mcser.Org/Journal/Index.Php/Mjss/Article/View/7122.

8. Khamis, S., \& Che Mohd Salleh, M. (2018). Study on the Efficiency of Cash Waqf Management In Malaysia. Journal of Islamic Monetary Economics And Finance, 4(1), 61-84. Https://Doi.Org/10.21098/ Jimf.V4i1.732.

9. Lahsasna, A. (2010). "The Role of Cash Waqf in Financing Micro and Medium Sized enterprises (mmes)."the role of cash waqf in the development of Islamic higher education in Bangladesh. In seventh international conference-the tawhidi epistemology: zakat and waqf economy, pp. 97-118.

10. Mokhtar, F. M., sidin, e. M., \& abd razak, d. (2015). Operation of cash waqf in malaysia and its limitations. Journal of islamic economics, banking and finance, 113(3158), 1-15.

11. Murat (book). A history of philanthropic foundations: the islamic world from.

12. Noor aimi bt mohd puad, nurauliani bt jamlus rafdi, wan shahdila shah bt shahar. (2014). "Issues and challenges of waqf instrument." (may): 978-83. 
13. Sanusi, S., \& Shafiai, M. H. M. (2015). The management of cash waqf: Toward socio-economic development of muslims in Malaysia. Jurnal Pengurusan, 43, 3-12.

14. Saifuddin, F. B., Kadibi, S., Polat, R., Fidan, Y., \& Kayadibi, O. (2014). The role of cash waqf in poverty alleviation: case of Malaysia.

15. Zuriadah, M. I., Nohidayah, A. and Rabitah, H. (2011). A Comparative Study of Waqf Management in Malaysia. IPEDR vol.10 (2011) @ (2011)IACSIT Press, Singapore. 